\title{
The Influence of Jodipan Color Utilization as a Learning Source of Ability to Solve Problems in The Theme of Enviromental Pollution
}

\author{
Latifatul Fauzi \\ himmalatifahanwar@gmail.com \\ Social Studies Program, Postgraduate Program, State University Of Surabaya, Indonesia \\ Ketut Prasetyo \\ ketutprasetyo@unesa.ac.id \\ Social Studies Program, Postgraduate Program, State University Of Surabaya, Indonesia \\ Mohammad Ali Haidar \\ m.alihaidar@ymail.com \\ Social Studies Program, Postgraduate Program, State University Of Surabaya, Indonesia
}

\begin{abstract}
The ability to solve problems is a process in which a person identifies a situation, formulates a hypothesis, verifies a hypothesis made by digging up data, and restarts the hypothesis made to become a generalization (Purwanto, 1999). The focus of this research is to analyze the influence of the use of the Kampung Warna Warni Jodipan as a source of learning for students' ability to solve problems in MTs Attaraqqie Malang on the theme of tackling environmental pollution. This study uses an experimental research design in the form of a Quasi-Experimental Design with the type of pretest posttest control group design. The sample in this study were students of class IX A and IX D with purposive sampling technique. Data collection techniques using test questions in the form of problem description. The data analysis technique in this study was to use the independent sample t-test.

The results of this study indicate that there is a significant influence on the use of the Kampung Warna Warni Jodipan as a source of learning for students' problem solving abilities, this is evidenced by the results of the independent sample t-test which shows that there is a significant influence on the use of the Kampung Warna Warni Jodipan., with tcount> ttable which is $5,450>2,000$. This shows that there are significant differences in the ability to solve problems in the experimental and control classes.
\end{abstract}

Keywords: problem solving skills, learning resources, Kampung Jodipan Colorful

\begin{tabular}{l}
\hline \hline Abstrak \\
\hline Kemampuan memecahkan masalah merupakan suatu proses dimana seseorang \\
mengidentifikasi sebuah keadaaan, merumuskan hipotesis, memferifikasi hipotesis yang \\
dibuat dengan menggali data, dan menyampaikan kembali hipotesis yang dibuat hingga \\
menjadi suatu generalisasi (Purwanto, 1999). Fokus dalam penelitian ini adalah untuk \\
menganalisis pengaruh pemanfaatan Kampung Warna Warni Jodipan sebagai sumber \\
belajar terhadap kemampuan memecahkan masalah siswa MTs Attaraqqie Malang pada \\
tema penanggulangan pencemaran lingkungan. Penelitian ini menggunakan desain \\
penelitian eksperimen dengan bentuk Quasi-Eksperimental Design dengan jenis pretest \\
posttest control group design. Sampel pada penelitian ini adalah siswa kelas IX Aan IX D \\
dengan teknik pengambilan sampel purposive sampling. Teknik pengumpulan data \\
menggunakan soal tes dengan bentuk soal uraian. Teknik analisis data dalam penelitian ini \\
adalah dengan menggunakan uji independent sample t-test. Hasil penelitian ini menjukkan \\
bahwa terdapat pengaruh yang signifikan pemanfaatan Kampung Warna Warni Jodipan \\
sebagai sumber belajar terhadap kemampuan memecahkan masalah siswa, hal ini \\
\hline \hline
\end{tabular}


dibuktikan dengan hasil Uji independent sample t-test yang menunjukkan bahwa terdapat pengaruh yang signifikan pemanfaatan Kampung Warna Warni Jodipan terhadap kemampuan memecahkan masalah, dengan nilai thitung $>$ tabel yaitu 5,450>2,000. Hal ini menunjukkan bahwa terdapat perbedaan yang signifikan kemampuan memecahkan masalah kelas eksperimen dan kontrol.

Kata kunci: kemampuan memecahkan masalah, sumber belajar, Kampung warna Warni Jodipan

Received : 06 September 2021 ; Revised: 22 November 2021 ; Accepted: 10 December 2021

(๑) ENTITA : Jurnal Pendidikan IImu

Pengetahuan Sosial dan IImu-IImuSosial https://doi.org/10.19105/ejpis.v3i2.4956

Institut Agama Islam Negeri Madura, Indonesia

\section{Introduction}

One of the problems faced in social studies lessons is the tendency for the management of teaching and learning conducted by teachers more oriented towards oneway communication patterns, namely from teachers to students. Conventional verbal learning based on the description model that many social studies teachers develop is still considered unsuccessful in creating meaningful social studies learning for students' lives. Most of the students are unable to connect the material learned with how the material is utilized in the surrounding social life. This is what makes Social Studies learning has a lot of criticism from many circles (Suprijono, 2009).

According to Lyons (2012) learning is a complex activity that involves the interaction of student motivation, physical facilities, teaching resources, and teaching skills and curriculum demands. The availability of learning resources can increase the effectiveness of good learning in students (Okongo, 2015). Mwiria (1985) also supports that student performance is influenced by the quality and quantity of teaching and learning materials (Okongo, 2015). In the learning process a teacher is tasked with preparing a conducive situation for students to understand what is being learned by giving facts, data, and concepts. According to Hermasyah and Sumarno (2003, p.4), implementing a variety of strategies, methods, and approaches that are appropriate to the conditions of students and material is needed because if learning is used that makes students interested, student learning outcomes will increase, so students become happy to learn further, and the ability to solve problems in students becomes honed.

During this learning process has not provided direct experience for students. The existence of the Kampung Warna Warni Jodipan Tourism Village is expected to be a source of learning that is relevant for students in improving the ability to solve problems in overcoming environmental problems. The problem of population growth is around $1.58 \%$, 
with the highest level of population density being Klojen Subdistrict, which is 11,792 people per square kilometer (Central Statistics Agency of Malang, 2016).

The high increase in population has caused various problems, especially environmental problems, one of which is the large number of slums on the Brantas River border. Jodipan slum located on the border of the Brantas River causes a decrease in the quality of river water due to the activities of the surrounding population. Residents in the Jodipan area use the Brantas river as a means to meet their daily needs, such as bathing, washing, and toilet without going through regular sanitation, disposal of household waste. With the creativity of UMM students (Muhamadiyah University of Malang) and the hard work of the local community, making Kampung Warna Warni Jodipans in Jodipan Urban Village undermined the intention of the Malang City Government to relocate residents. The Mayor of Malang is very supportive, Jodipan Village becomes the new Tourism Destination Area as a city tour.

According to R.T.M Sutamihardja (1978, p.1), states: "Pollution is the addition of various kinds of materials as a result of human activities to the environment and usually exert a harmful influence on the environment". Human activities that pollute the environment that often occur in the city of Malang are expected to be a contextual learning for students. The management of the Kampung Warna Warni Jodipan as an effort by the local community to tackle environmental pollution around the border of the Brantas River, is expected to be a real source of learning for students.

The use of Kampung Warna Warni Jodipan as a source of learning through inquiry models is expected to improve students' problem solving abilities. With these learning resources can foster student interest in the object to be studied, students are also given the opportunity to explore their ability to collect and analyze information obtained. At the end of learning, students are expected to be able to draw conclusions from their findings, while students are also triggered to give birth to their creativity to provide several other alternatives in solving similar problems that might occur in their homes.

The purpose of this study was to analyze the effect of the use of the Kampung Warna Warni Jodipan as a learning resource on students' problem solving abilities on the theme of tackling environmental pollution. 


\section{Materials And Methods}

This research was conducted from February to March 2019 at MTs Attaraqqie Malang, Indonesia. This study applies the use of Kampung Warna Warni Jodipan as a learning resource for students' problem solving abilities on the theme of tackling environmental pollution.

\subsection{Problem Solving Ability}

The ability to solve problems is a process in which a person identifies a situation in which there is a problem, formulates tentative expansion or hypothesis, verifies hypotheses created by cutting and evaluating data, and restarts hypotheses that are made up to become generalizations (Purwanto, 1999). Problem solving skills are part of the social studies curriculum which is quite vital because in the learning process and its completion, it is possible for students to gain experience using the knowledge and skills they have to apply to problem solving (Abdurrahman, 2009, p.257).

A problem has challenges that are not yet known the right set of problems that will be given to students to determine the category of whether or not a question becomes a problem or formulation that there is only an ordinary question. Therefore it can happen that a problem question for one student, will become a normal question for other students because he already knows the procedure for solving it (Zakaria, 2007, p.143).

The problem-solving ability of students is emphasized in the process of thinking about efforts to solve problems and to process the data obtained. The four steps to solving the problem are to understand the problem, to plan the problem, to solve the problem and to review it (Abdurrahman, 2009). Troubleshooting can be seen as the process of applying existing knowledge and understanding to something new to gain new ideas and insights. The main emphasis of problem solving as a teaching strategy is to help students develop an understanding of the scientific principles and concepts contained in the problem (Nasution, 2015).

Wena (2009: 52) states that solving problems is not merely a form of skill in applying rules that have been mastered through previous learning activities, but also a process for obtaining some rules at a higher level. If someone has obtained a series of stages that can be operated in accordance with the situation at hand, it means that someone can already be said to be able to overcome a problem.

\subsection{Learning Resources}


The definition of learning resources according to the AECT (Association for Educational Communications and Technology) defines learning resources as all sources (data, people, and goods) that can be used by students as a separate source or in combination to facilitate learning and include messages, people, materials, tools, techniques and the environment. Learning resources even change into instructional system components if the learning resources are pre-arranged (prestructured), designed and selected then combined into a complete instructional system so as to result in purposeful and controlled learning.

\subsubsection{Kampung Warna Warni Jodipan}

Slums area are a problem that is often found in urban areas. Those who live in slums are generally people with low economic conditions. Indonesia is one country that has problems related to slums, for example as happened in an area of Malang City. Jodipan Village is the area which is a picture of slums in Malang City, located on the border of a river, precisely in Brada in alley 1, Jodipan, Blimbing, Kesatrian, Blimbing, Malang City, East Java. Many problems arise from community behavior in Jodipan slums. As for the problems that occur in Jodipan village, among others: one, Jodipan village is a village with a high population density. It can be seen that based on BAPPEDA, Jodipan village has an area of 49 ha with a population of 13,201 inhabitants.

The transformation of the village took place thanks to the initiative of a number of Communication Studies students from the University of Muhammadiyah Malang who were members of the Guyspro group. They were inspired by a colorful checkered house in the village of Favela, Rio de Janeiro, Brazil. and the City of Cinque Terre, Italy, the concept was applied to the Jodipan village by painting the outer wall to the roof of the house in various colors. The colors that are applied in each house are different, ranging from red, orange, yellow, green, blue, purple, pink, and so on. The students' ideas were then welcomed by one of the paint producers in Malang and painting was carried out by the community with the help of the army in June 2016.

Not only by playing colors, but also applying various forms of murals, such as $2 \mathrm{D}$ and 3D images. Figure 2. Kampung Warna Warni Jodipan as a result of processing slums in the border of the Brantas River. Significant differences were seen between Jodipan village past and present. Previously, Jodipan village was not well maintained, from the amount of rubbish that was scattered on the border of the river, the arrangement of houses piled up, to the walls and roofs of the house that were not maintained and looked worn-out because 
it had not been repaired. While now it has metamorphosed into a more beautiful and attractive village.

\section{Method}

This study uses experimental research design with the form of Quasi-Experimental Design with the type of pretest posttest control group design. This study used two groups, namely the experimental group and the control group, the sample in this study were students of class IX A and IX D with purposive sampling technique. The technique of collecting data uses test questions with the description form. This method is used to determine students' memecahkan masalah skills before being given treatment and after being treated by using instruments in the form of test questions, namely pre-test and post-test.

The data analysis technique used is divided into two stages. The first step is to test the analysis prerequisites to determine what type of analysis will be used to test the research hypothesis. While the second stage of data analysis is to test the hypothesis that has been proposed. Data analysis techniques to test the hypotheses that have been proposed are to use the independent sample t-test.

\section{Results And Discussion}

To find out the comparison of the initial value of the ability to solve the problem of the experimental class and the control class before learning with different models, an initial test (pretest) was assessed. The results of the initial tests of problem solving skills of the experimental and control class students are presented in the following data description table:

Table 1.

\begin{tabular}{|c|c|c|}
\hline $\begin{array}{l}\text { Descriptive } \\
\text { statistical results }\end{array}$ & Experiment Class & Control Class \\
\hline N Valid & 35 & 30 \\
\hline Mean & 17,43 & 16,80 \\
\hline Median & 18,00 & 16,00 \\
\hline Minimum & 12 & 10 \\
\hline Maximum & 22 & 20 \\
\hline
\end{tabular}

The test results presented in the above table can be seen the pretest value of 35 experimental class students from 30 maximum scores, the experimental class obtained an average value of 17.43 , a median of 18.00 , a minimum value of 12.00 and a maximum value of 22.00. While the results of the pretest scores of 30 control class students with an average 
of 16.80 , a median of 16.00 , a minimum value of 10.00 , and a maximum value of 20.00 . From these data it can be seen that the pretest scores of the two classes are not far adrift. So it can be concluded that the initial ability to solve students' problems both in the experimental class and in the control class is almost the same.

The results of the pretest value are also evidenced by the results of hypothesis testing through independent sample $t$ test. As for the Hypothesis Test the initial test of students' problem solving skills is:

$\mathrm{HO}$ : There is no significant difference in the ability to solve problems between the experimental class and the control class

$\mathrm{H} 1$ : There is a significant difference in the ability to solve problems between the experimental class and the control class

Decision making and drawing conclusions on the hypothesis test Research Initial tests of the ability to understand the concept carried out at a significance level of $5 \%(0.05)$. The submission criterion is if the significance value $\alpha>0.05$, then $\mathrm{H} 0$ is accepted and $\mathrm{H} 1$ is rejected. And vice versa if the value $\alpha<0.05$, then $\mathrm{H} 0$ is rejected and $\mathrm{H} 1$ is accepted. And $\mathrm{HO}$ is rejected and $\mathrm{H} 1$ is accepted if $\mathrm{t}>\mathrm{t}$ table. Conversely, $\mathrm{HO}$ is accepted and $\mathrm{H} 1$ is rejected if tcount <ttable. The results of the t-test hypothesis test using the SPSS 24.00 program are presented in Table 2 below:

\section{Table 2}

Test Results Independent Sample t-test Value Pretest Ability of students problem solving

\begin{tabular}{llllll}
\hline \multicolumn{5}{c}{ t-test for Equality of Means } \\
\hline Mean & & & Sig. \\
(2-tailed) & Mean Difference \\
\hline Kontrol & Eksperimen & & & & \\
\hline 16,8 & 17,4 & 0.872 & 63 & 0,387 & 0,629 \\
\hline
\end{tabular}

Based on SPSS 24.00 output in the table it is known that the t-value is 0.872 and ttable with a significance level $(5 \%) 0.05$, degree of freedom $(d b)=(n-2)$, then $t(0.05)(60)$ table $=2,000$ is obtained . Then the results of tcount $<$ ttable, which shows the results 0.872 $<2,000$. As for the significance level of $5 \%(0.05)$ has a significance value $\alpha>0.05$, i.e. (2tailed) $0.387>0.05$. So it can be concluded that there is no significant difference in the ability to solve problems between the experimental class and the control class before being given treatment, meaning that between the experimental class and the control class students have more or less the same ability to solve problems at the time of the pretest. This is reinforced 191 
by the experimental class which obtained an average value of 17.4 and the control class had an average value of 16.8 .

After getting treated with a different learning model during three meetings, a final assessment (posttest) of the ability to solve problems in the experimental class and the control class was carried out. The posttest problem solving ability consists of three questions in the form of descriptions with a maximum score of 30 . To find out the posttest scores of the two classes will be explained in the table below:

\section{Table 3}

\section{Postest Value Data Solve Problems of Experiment and Control Classes}

\begin{tabular}{lll}
\hline Hasil statistik Deskriptif & \multicolumn{1}{c}{ Kelas Eksperimen } & Kelas Kontrol \\
\hline N Valid & $\mathbf{3 5}$ & $\mathbf{3 0}$ \\
Mean & 25,26 & 22,60 \\
Median & 24,00 & 24,00 \\
Minimum & 22 & 18 \\
Maximum & 28 & 26 \\
\hline
\end{tabular}

In the table above can be seen the posttest scores of 35 experimental class students with an average of 25.26, a median of 24.00 , a minimum value of 22 and a maximum value of 28 . While the results of the pretest scores of 30 control class students with an average of 22,60 , median 24.00 , minimum value 18 , and maximum value 26 . From these data it can be seen that the posttest scores of the two classes have significant differences. So it can be concluded that the ability to solve the problem of experimental class students after learning with the inquiry model by utilizing the Kampung Warna Warni Jodipan as a source of learning is higher than the control class that uses the PBL (Problem Based Learning) learning model.

The posttest value of students' problem solving skills is also evidenced by hypothesis testing through independent sample t test. Test Hypothesis research final test of students' problem solving skills are:

$\mathrm{HO}$ : There is no significant difference in the ability to solve problems between the experimental class and the control class

$\mathrm{H} 1$ : There is a significant difference in the ability to solve problems between the experimental class and the control class

Decision making and drawing conclusions on the hypothesis test Research Final test ability to solve the problem is done at a significance level of $5 \%(0.05)$. The submission 
criterion is if the significance value $\alpha>0.05$, then $\mathrm{HO}$ is accepted and $\mathrm{H} 1$ is rejected. And vice versa if the significance value $\alpha<0.05$, then $\mathrm{H} 0$ is rejected and $\mathrm{H} 1$ is accepted. The $\mathrm{H} 0$ will be rejected and $\mathrm{H} 1$ accepted if $\mathrm{t}>\mathrm{t}$ table. Conversely, $\mathrm{H} 0$ is accepted and $\mathrm{H} 1$ is rejected if tcount <ttable. The results of the t-test hypothesis test using the SPSS 24.00 program are presented in Table 4.28 below.

\section{Table 4.}

\section{Test Results Independent Sample t-test Value Postest Test Ability to Solve Problems}

\begin{tabular}{|c|c|c|c|c|}
\hline & \multicolumn{4}{|c|}{ t-test for Equality of Means } \\
\hline Mean & $\mathrm{T}$ & Df & $\begin{array}{l}\text { Sig. } \\
\text { (2-tailed) }\end{array}$ & Mean Difference \\
\hline Kontrol & Eksperimen & & & \\
\hline 22,6 & 5,450 & 63 & 0,000 & 2,657 \\
\hline
\end{tabular}

Based on SPSS 24.00 output in the table it is known that the t-value is 5.450 and ttable with a significance level (5\%) 0.05 , degree of freedom $(\mathrm{db})=(\mathrm{n}-2)$, then $\mathrm{t}(0.05)(60)$ table $=2,000$ is obtained. Then the results of tcount $>$ ttable, which shows the results $5,450>$ 2,000 . As for the significance level of $5 \%(0.05)$ has a significance value $\alpha<0.05$, i.e. sig (2tailed) $0,000<0.05$. So it can be concluded that there is a significant difference in the ability to solve problems between the experimental class and the control class after being given treatment, meaning that the results of the ability to solve the problem of the experimental class after being treated by utilizing Kampung Warna Warni Jodipan as a source of learning are better than the control class using the learning model PBL (Problem Based Learning). This is reinforced by the higher value of the experimental class which is 12.63 and the control class has an average value of 22.6.

The results of the data exposure above indicate that the ability to solve problems in the experimental class that utilizes the Kampung Warna Warni Jodipan of Jodipan as a source of learning is higher than the control class that is learning with the PBL (Problem Based Learning) model. The results of these observations can be seen at the second and third meetings, where the experimental class shows a significantly higher average value. This is influenced by experience and direct investigation in the field, so that students more easily provide alternative solutions to environmental problems. 


\section{Conclusion}

Hypothesis test results indicate that there are significant differences in the ability to solve the problem of experimental class students who use Kampung Warna Warni Jodipan as a learning resource, and the control class that uses the PBL (Problem Based Learning) learning model. Where the experimental class shows a better value than the control class. This is due to the experimental class learning, students can develop their creativity to develop problem solving that occurs, also design solutions to problems that occur elsewhere, or at other times. The existence of the Kampung Warna Warni Jodipan as a source of learning really helps students to observe directly the existing problems. Students to collect as much information about the behavior of the community as a cause of environmental pollution, the impact caused, and the countermeasures made. This has implications for the results of students' problem solving skills.

\section{References}

Abdurrahman, Mulyono. (2009). Pendidikan Bagi Anak Berkesulitan Belajar, Jakarta: Rineka.

Arikunto, Suharsimi. (2010). Manajemen Penelitian. Jakarta: Rineka Cipta.

Bušljeta, R. (2013). Effective Use of Teaching and Learning Resources. Czech-Polish Historical and Pedagogical Journal, 5/2, 55-69. doi: 10.2478/cphpj-2013-0014.

Crisolo, Oliver R., Sandy Camposano, dan Danilo V. Rogayan . 2017. Relevance of social studies in the 21 st century society: Students' perspectives. Ramon Magsaysay Technological University, Castillejos, Zambales.

Darmawan, Deni. (2013). Metode Penelitian Kuantitatif. Bandung: PT. Remaja Rosdakarya. Hardika. (2012). Pembelajaran Transformatif berbasis Learning How To Learn. Malang: UMM Press.

Heinström, Jannica and Eero Sormunen, (2016). Students' collaborative inquiry - Relation to approaches to studying and instructional intervention. https://doi.org/10.1177/0165551515621838.

Nasution. (2015). Kajian Pembelajaran IPS Di Sekolah. Surabaya: Unesa University Press. Purwanto, Edy. (1999). Desain Teks Untuk Belajar "Pendekatan Pemecahan Masalah". Jurnal IPS dan Pengajarannya. Vol. 33, No. 2, pp: 283 - 296

Rindell, Amelia J. Abern. (1999). Applying Inquiry Based Learning and Cooperative Group Learning Strategies to promote Critical Thinking. JCST. Page: 203 
Shoimin, Aris. (2014). 68 Model Pembelajaran Inovatif dalam Kurikulum 2013. Yogyakarta: Ar-Ruzz Media.

Sriarunrasmee, Jaemjan, Praweenya Suwannatthachoteb, Pimpan Dachakupt. 2015. Virtual Field Trips with Inquiry learning and Critical Thinking Process: A Learning Model to Enhance Students' Science Learning Outcomes. Procedia - Social and Behavioral Sciences 197 ( 2015 ) 1721 - 1726. doi: 10.1016/j.sbspro.2015.07.226. Stewart, katie s. saunders, petra d. t. gyles, bruce m. shore, (2012). student outcomes in inquiry instruction. a literature-derived inventory. https://doi.org/10.1177/1932202x11429860.

Sugiyono. (2017). Metode Penelitian Pendidikan: Pendekatan Kuantitatif, Kualitatif, dan $R \& D$. Bandung: Alfabeta.

Suprijono, Agus. 2009. Pengaruh Live Model, Symbolic Model, Dan Verbal Description Model Tterhadap Pemahaman Siswa SMA Tentang Konsep Sosiologi. Jurnal IImu Pendidikan, Vol. 16, No. 3, pp: 135-142.

Sutamihardja, RTM. (1978). Kualitas dan Pencemaran Lingkungan, Sekolah Pascasarjana, IPB Bogor.

Trianto. 2007. Model Pembelajaran Terpadu dalam Teori dan Praktek. Jakarta: Prestasi Pustaka Publisher

Wena, Made. (2009). Strategi Pembelajaran Inovatif Kontemporer. Jakarta: PT. Tiga Aksara.

Zakaria, Effendi. (2007). Trend Pengajaran dan Pembelajaran Matematik. Kuala Lumpur, Lohprint SDN, BHD. 
Latifatul Fauzi, Ketut Prasetyo, Mohammad Ali Haidar,

ENTITA Vol. 3 No. 2, December 2021 